18. Про внесення змін до Земельного кодексу України (щодо права власності іноземних інвесторів на землю): проект Закону України від 15 квітня 2016 p. № 4455. Офіційний веб-портал Верховної Ради України. URL: http:// w1.c1.rada.gov.ua/pls/zweb2/webproc4_1?pf3511=58767.

19. Лист Американської торгівельної палати в Україні до Голови Верховної Ради України. URL: publications.chamber.ua/2016/.../PP_Groisman_updated.doc.

20. Рішення господарського суду Закарпатської області від 28 жовтня 2008 р. у справі № 11/64. Єдиний державний реєстр судових рімень. URL: www.reyestr.court.gov.ua/Review/ 2283117.

21. Постанова Севастопольського апеляційного господарського суду від 18 листопада 2008 р. у справі № 2-8/8089-2008. Єдиний держсавний реєстр судових рімень. URL: http://reyestr.court.gov.ua/Review/12328501.

22. В центрі уваги: права власності на землю: Аналітичний звіт, підготовлений Комітетом 3 питань нерухомості та Правничим комітетом Свропейської Бізнес Асоціації. 2007. 11 с.

23. Соловцова О. П. Продаж земельних ресурсів іноземним інвесторам: вітчизняна та закордонна практика. URL: ea.donntu.edu.ua/.../Продаж\%20 земельних\%20ресурсів\%2.

24. Близнюк П. Емфітевзис як альтернатива оренді землі. Агро. URL: https://uteka.ua/ua/ publication/Emfitevzis-yak-alternativa-orendi-zemli.

УДК 346.12:347.413:347.764

Ю. O. Moicetв доцент кафедри господарського права Донецького національного університету імені Василя Стуса, канд. юрид. наук, доцент

Ю. П. Уралова старший викладач кафедри цивільного права і процесу Донецького національного університету імені Василя Стуса

\title{
ЩОДО ЗАСТОСУВАННЯ ОПЕРАТИВНО-ГОСПОДАРСЬКИХ ТА АДМІНІСТРАТИВНО-ГОСПОДАРСЬКИХ САНКЦІЙ ДО СУБ'ЄКТІВ ПОСЕРЕДНИЦЬКОЇ ДІЯЛЬНОСТІ У СФЕРІ СТРАХУВАННЯ
}

Ключові слова: суб’єкти страхового посередництва, страхове посередництво, страхові брокери, перестрахові брокери, страхові агенти, форми господарсько-правової відповідальності, оперативно-господарські санкиї, адміністративно-господарські санкиії.

Однією з передумов належної організації діяльності страхових посередників в сучасних умовах господарювання є законодавче забезпечення дотримання правил при здійсненні цієї діяльності, підтримання договірної дисципліни, належного виконання страховими посередниками господарських зобов'язань. Вирішення цього питання залежить від ефективності дії механізму правового 
регулювання посередницької діяльності у сфері страхування, конкретного правового засобу, здатного своїм впливом попередити господарське правопорушення, а у випадку його вчинення - усунути негативні господарські результати та не допустити їх повторення. Таким правовим засобом є господарсько-правова відповідальність суб'єктів посередницької діяльності у сфері страхування.

На сьогодні застосування господарсько-правової відповідальності до страхових посередників відбувається за загальними правилами застосування цієї відповідальності до учасників господарських відносин. В цьому контексті доцільно звернути увагу, що загальні положення щодо підстав, умов та форм господарськоправової відповідальності, які поширюються на суб'єктів посередницької діяльності у сфері страхування, встановлено Господарським кодексом України (далі - ГК України), проте вони не враховують особливості цієї діяльності.

Водночас варто підкреслити, що у Законі України «Про страхування» та інших нормативно-правових актах, які містять спеціальні норми стосовно посередницької діяльності у сфері страхування, відсутні положення щодо таких важливих форм господарсько-правової відповідальності як застосування оперативно-господарських та адміністративно-господарських санкцій. Як наслідок, застосування цих санкцій до суб’єктів посередницької діяльності у сфері страхування супроводжується виникненням низки проблем, має обмежений i малоефективний характер.

Загальні питання та окремі аспекти застосування різних форм господарсько-правової відповідальності розглядалися у роботах А. Г. Бобкової, О. М. Вінник, І. О. Віхрової, С. Ю. Гапало, О. І. Гелевей, О. А. Заярного, Д. Х. Липницького, В. К. Мамутова, О. М. Новошицького, В. І. Новошицької, О. А. Печеного, 3. Ф. Татькової, В. С. Щербини та ін. Однак, питання щодо особливостей застосування оперативно-господарських та адміністративно-господарських санкцій до суб'єктів посередницької діяльності у сфері страхування не одержало достатньої наукової розробки.

Вищенаведене вказує на актуальність теми цієї статті та доцільність иї дослідження.

Метою статті є обтрунтування пропозицій щзодо застосування оперативно-господарських та адміністративно-господарських санкиій до суб'єктів посередницької діяльності у сфері страхування.

Реалізація господарсько-правової відповідальності суб'єктів посередницької діяльності у сфері страхування здійснюється через визначені у законодавстві форми такої відповідальності. У зв'язку з цим у науковій літературі зазначається, що застосування різних форм господарсько-правової відповідальності стимулює до належного виконання зобов'язань, компенсує збитки та сигналізує про правопорушення [1, с. 258].

При дослідженні такої форми господарсько-правової відповідальності як застосування оперативно-господарських санкцій, варто враховувати положення ст. 235 ГК України [2]. Згідно з ч. 1 цієї статті за порушення господарських зобов'язань до суб'єктів господарювання можуть застосовуватись оперативногосподарські санкції, які представляють собою заходи оперативного впливу на 
правопорушника з метою припинення або попередження повторення порушень зобов'язання, що використовуються самими сторонами зобов'язання в односторонньому порядку. При цьому до суб'єкта, який порушив зобов'язання, можуть бути застосовані ті оперативно-господарські санкції, застосування яких передбачено договором. Ці положення поширюються й на суб'єктів посередницької діяльності у сфері страхування,

Досить часто страхові компанії використовують такі види оперативногосподарських санкцій, як відмова від виплати винагороди страховому посереднику у разі неналежного виконання ним своїх зобов'язань або зміна порядку виплати винагороди страховому посереднику, який порушив зобов'язання.

Водночас, як зазначає С. Ю. Гапало, існує проблема поняття, сутності, якісних характерних ознак, підстав і порядку застосування оперативно-господарських санкцій, яка на даний момент $є$ досить актуальною, зважаючи на той факт, що норми, які врегульовують функціонування останніх, були вперше закріплені на законодавчому рівні в результаті прийняття ГК України [3, с. 12].

На підтвердження наведеного слід зазначити, що на практиці при застосуванні оперативно-господарських санкцій виникають спірні питання щодо наявності підстав для застосування, порядку їх застосування, зловживання правом в односторонньому порядку застосовувати такі санкції. Вказані спірні питання є актуальними при застосуванні до суб'єктів господарювання цих санкцій незалежно від виду господарської діяльності, у тому числі стосуються діяльності страхових посередників. Тому є необхідним опрацювання найбільш спірних з перерахованих питань щодо застосування оперативно-господарських санкцій до страхових посередників.

Правила щодо підстав та порядку застосування цих санкцій визначаються ст. 237 ГК України, де зокрема зазначено, що достатньою підставою для застосування оперативно-господарських санкцій $є$ факт правопорушення. У досліджуваних відносинах факт правопорушення полягає у порушенні умов посередницького договору, що може виражатися у дії (наприклад, перевищення страховим агентом своїх повноважень), або у бездіяльності (наприклад, невиконання страховим посередником своїх зобов’язань щодо укладання договорів).

Особливості встановлення такого факту в процесі застосування оперативногосподарських санкцій полягають у тому, що наявність такого факту, тобто підстав для їх застосування, визначається безпосередньо стороною договору, внаслідок чого ця ж сторона без звернення до юрисдикційних органів самостійно приймає рішення про притягнення до відповідальності правопорушника.

Отже, оперативно-господарські санкції являють собою втілення делегованого державного примусу, який виражається в наданні сторонам у зобов'язанні права застосовувати ці санкції без звернення до компетентного юрисдикційного органу. Таке «делегування» державного примусу чітко простежується в нормах ст. ст. 235 та 237 ГК України, які надають можливість застосування оперативно-господарських санкцій сторонами господарських правовідносин у позасудовому порядку та без попереднього пред’явлення претензії порушнику зобов'язання [3, с. 11]. 
Порядок застосування конкретних оперативно-господарських санкцій за порушення при здійсненні посередницької діяльності у сфері страхування має визначатись договором про надання страхових агентських послуг та договором про надання страхових брокерських послуг. Відтак, за відсутності відповідних положень на рівні законодавства постає питання щодо таких важливих аспектів порядку застосування оперативно-господарських санкцій, як фіксація факту правопорушення, визначення строку застосування таких санкцій відносно страхових посередників та оскарження застосування цих санкцій.

У науковій літературі неодноразово звертали увагу на необхідність розширення юридичних підстав для застосування оперативно-господарських санкцій, визнаючи у якості такої підстави не тільки договір, а й нормативноправові акти, у тому числі підзаконні. При цьому слід відзначити, що Положення про порядок провадження діяльності страховими посередниками, затверджене постановою Кабінету Міністрів України від 18.12.1996 р. № 1523 (далі - Постанова № 1523) наразі передбачає застосування санкції, яка за своїм характером є оперативно-господарською. Так, у разі несвоєчасного перерахування страховим агентом страхових платежів або порушення ним терміну оформлення договорів страхування без поважних причин страховик зобов'язаний призупинити дію агентської угоди не менше ніж на три місяці [4].

Зважаючи на це, варто підтримати думку 3. Ф. Татькової, яка пропонує ч. 2 ст. 235 ГК України після слів «передбачено договором» доповнити словами «або законодавством» [5, с. 14]. За такого підходу в окремому розділі Постанови № 1523 «Відповідальність страхових посередників» доцільно визначити розширений перелік оперативно-господарських санкцій та правопорушення, які $\epsilon$ підставою застосування таких санкцій, не обмежуючи учасників страхових відносин в праві передбачити у конкретному посередницькому договорі інші оперативно-господарські санкції.

3 урахуванням ознак цих санкцій, підстав та порядку їх застосування, строк, протягом якого управнений суб'єкт має право застосувати оперативногосподарські санкції, має бути скороченим порівняно із строками застосування інших господарсько-правових санкцій, інакше втрачається їх основне призначення. Беручи це до уваги, слід підтримати пропозицію З. Ф. Татькової, яка вважає, що таким строком слід визнати один місяць від дня виявлення порушення та не більше трьох місяців від дня його вчинення [5, с. 12].

Для того, щоб виключити будь-які непорозуміння щодо наявності фактичної підстави застосування оперативно-господарських санкцій, стороні договору, чиї права порушені, доцільно скласти відповідний акт про порушення. Так, на думку П. Гуйвана, такий акт є правовим документом, який встановлює факт порушення і є одним із засобів доказування при вирішенні питання про відшкодування завданої даним порушенням шкоди [6, с. 288]. А тому, враховуючи складність відносин, які виникають в процесі виконання господарських договорів, варто підтримати пропозицію 3.Ф. Татькової щодо доцільності включення до порядку застосування оперативно-господарських санкцій обов'язку сторони договору, яка потерпіла від правопорушення, по складанню акту, в 
якому повинен бути документально зафіксований факт правопорушення, що підтверджує наявність фактичної підстави для застосування оперативногосподарських санкцій цією стороною договору, на основі правової підстави, передбаченої договором або законодавством [5, с. 13].

3 урахуванням цього пропонується у Положенні про порядок провадження діяльності страховими посередниками передбачити вимогу, згідно 3 якою при виявленні правопорушення, яке може бути підставою застосування оперативногосподарських санкцій, в обов'язковому порядку складається акт про виявлення правопорушення.

За загальним правилом застосування оперативно-господарських санкцій здійснюється незалежно від вини порушника господарського зобов'язання. У той же час, оскільки такі санкції застосовуються за ініціативою сторони зобов'язання, що постраждала від порушення, то невинуватість сторони зобов'язання порушника може вплинути на рішення щодо застосування до неї санкцій. 3 урахуванням цього, якщо в посередницькому договорі передбачені оперативногосподарські санкції, то страховий посередник, який порушив своє зобов'язання або знає, що порушить його при настанні строку виконання, має повідомити про це іншу сторону. Це може запобігти застосуванню до нього зазначених санкцій.

Види оперативно-господарських санкцій визначаються ст. 236 ГК України, яка не передбачає їх закритого переліку. 3 урахуванням положень зазначеної статті ГК України можна запропонувати у Примірному договорі про надання страхових агентських послуг та Примірному договорі про надання страхових брокерських послуг (які може рекомендувати Національна комісія, що здійснює державне регулювання у сфері ринків фінансових послуг) закріпити перелік цих санкцій, які можуть бути застосовані до страхового посередника у разі порушення договірних зобов'язань. До цих санкцій можна віднести такі: відмова страхувальника від виконання свого зобов'язання із звільненням його від відповідальності у разі порушення страховим посередником своїх зобов'язань; відмова страхувальника від оплати винагороди брокера (повністю або частково), у разі неналежного виконання страховим посередником своїх обов'язків; відмова страхувальника або страховика від прийняття зобов'язання, виконаного страховим посередником 3 порушенням строків виконання; зупинення дії агентської угоди в односторонньому порядку на строк до трьох місяців у разі несвоєчасного перерахування страховим агентом страхових платежів або порушення ним терміну оформлення договорів страхування без поважних причин; односторонне припинення дії посередницького договору на строк до трьох місяців або його розірвання у разі повторного невиконання або неналежного виконання страховим посередником своїх зобов'язань.

Зазначений перелік оперативно-господарських санкцій є примірним, тому сторони можуть передбачити в посередницькому договорі інші санкції. При цьому сторони одночасно з вибором санкції повинні конкретизувати підставу і порядок іï застосування. В основу вибору конкретних санкцій можуть бути покладені як загальні норми про зобов'язання, так і норми про окремі їх види. 
Ще однією формою господарсько-правової відповідальності суб'єктів посередницької діяльності у сфері страхування $є$ застосування адміністративногосподарських санкцій за порушення правил здійснення господарської діяльності. Відповідно до ст. 238 ГК України під адміністративно-господарськими санкціями розуміють заходи організаційно-правового або адміністративного характеру, спрямовані на припинення правопорушення суб'єктом господарювання та ліквідацію його наслідків, які застосовуються уповноваженими органами державної влади та місцевого самоврядування. При цьому види адміністративногосподарських санкцій, умови та порядок їх застосування визначаються ГК України, іншими законодавчими актами. Адміністративно-господарські санкції відповідно до ч. 2 ст. 238 ГК України можуть бути встановлені виключно законами.

Загальна класифікація видів адміністративно-господарських санкцій закріплена у ст. 239 ГК України. При цьому у науковій літературі залежно від характеру спрямування адміністративно-господарські санкції поділяють на дві великі групи. Перша група - господарсько-організаційні санкції, тобто передбачені законом заходи організаційного впливу (обмеження) на суб'єкта господарювання, що застосовуються компетентними державними органами або за їх ініціативою судом у передбачених законом випадках. До таких санкцій можна віднести зупинення дії ліцензії, скасування державної реєстрації тощо. Друга група - адміністративно-майнові санкції, тобто передбачені законом заходи майнового впливу на порушника, що застосовуються компетентними органами у передбачених законом випадках. До таких санкцій належать адміністративногосподарський штраф, господарська конфіскація тощо [7, с. 390].

Аналіз положень ГК України щодо адміністративно-господарських санкцій дозволяє зробити такі висновки. По-перше - у якості фактичної підстави застосування цих санкцій виступає порушення встановлених законодавчими актами правил здійснення господарської діяльності, відповідно, юридичною підставою $є$ виключно закони. По-друге, від різновиду санкції залежить механізм іiі застосування: (а) адміністративний порядок (за рішенням компетентних органів виконавчої влади чи органів місцевого самоврядування); (б) судовий порядок (за рішенням суду у випадках передбачених законом).

Разом 3 тим стосовно посередницької діяльності у сфері страхування можна знайти певні суперечності вищевказаним загальним правилам. Так, відповідно до п. 3.3 Порядку реєстрації страхових агентів, які мають право здійснювати посередницьку діяльність з обов'язкового страхування цивільноправової відповідальності власників наземних транспортних засобів Дирекція МТСБУ приймає рішення про виключення страхового агента з реєстру, у тому числі у разі виявлення при проведенні Національною комісією, що здійснює державне регулювання у сфері ринків фінансових послуг, перевірки страховика порушень страховим агентом законодавства про фінансові послуги, у тому числі виявлення невідповідності страхового агента професійним якостям та діловій репутації, встановленим Кваліфікаційними вимогами [8].

Також згідно 3 п. 7.5. Положення № 736 Нацкомфінпослуг приймає розпорядження про виключення страхового (перестрахового) брокера з Реєстру 
в разі: установлення фактів подання недостовірної інформації в документах, які були підставою для внесення страхового (перестрахового) брокера до Реєстру; невиконання припису Нацкомфінпослуг [9].

Вищевказана санкція у вигляді виключення 3 реєстру має ознаки адміністративно-господарської санкції і має на меті припинення правопорушення, а саме, невідповідність страхового агента професійним якостям та діловій репутації, встановленим Кваліфікаційними вимогами, та порушень щодо відповідності страхового брокера або невиконання ним приписів. Разом з тим дирекція МТСБУ відповідно до чинного законодавства не $\epsilon$ уповноваженим державним органом щодо застосування адміністративно-господарських санкцій, а підстави і самі санкції передбачені підзаконними нормативно-правовими актами, що не узгоджується з вимогами ст. 238 ГК України.

3 урахуванням цього можна запропонувати, щоб адміністративногосподарські санкції, які можуть бути застосовані до страхових посередників, в т. ч. виключення з державного реєстру страхових посередників, були б визначені Законом України «Про страхування». А саме, названий Закон доцільно доповнити положеннями щодо (а) конкретного переліку правопорушень, за які можуть бути застосовані адміністративно-господарські санкції (зокрема, невідповідність страхового агента професійним якостям та діловій репутації, встановленим Кваліфікаційними вимогами), (б) видів адміністративно-господарських санкцій, які можуть бути застосовані до страхових посередників (зокрема, адміністративно-господарський штраф, виключення з реєстру; зупинення діяльності до усунення порушень); (в) компетентного державного органу, який має право їх застосування (таким органом може бути Національна комісія, що здійснює державне регулювання у сфері ринків фінансових послуг).

Таким чином, на основі узагальнення вищевикладеного пропонується:

1) закріплення у примірних договорах про надання страхових агентських та брокерських послуг переліку оперативно-господарських санкиій, які можуть бути застосовані до страхового посередника у разі порушення договірних зобов'язань;

2) визначення на рівні Закону України «Про страхування» підстав застосування адміністративно-господарських санкиій до страхових посередників, видів таких санкиій, а також державного органу, уповноваженого на ӥх застосування.

Реалізація вказаних пропозицій дозволить стимулювати належне виконання своїх зобов'язань страховими посередниками та гарантувати захист прав та законних інтересів інших учасників страхового ринку. Разом з тим проведене дослідження не вичерпує всього комплексу проблем, пов'язаних із застосуванням оперативно-господарських та адміністративно-господарських санкцій до суб'єктів посередницької діяльності у сфері страхування, з урахуванням чого ці питання мають стати предметом подальшого наукового опрацювання.

1. Науково-практичний коментар Господарського кодексу України / за заг. ред. В. К. Мамутова. Київ: Юрінком Інтер, 2004. 688 с.

2. Господарський кодекс України: Закон України від 16 січня 2003 р. № 436-IV. Відомості Верховної Ради Украӥни. 2003. № 18-22. Ст. 144. (Із змінами). 
3. Гапало С. Ю. Санкції в господарському праві України: автореф. дис ... канд. юрид. наук: 12.00 .04 «Господарське право, господарсько-процесуальне право». ДВНЗ «Київський національний економічний університет імені Вадима Гетьмана». К., 2011. 23 с.

4. Про порядок провадження діяльності страховими посередниками: Постанова Кабінету Міністрів України від 18 грудня 1996 р. № 1523. Урядовий кур’єр. 1997. 21 січня.

5. Татькова 3. Ф. Підстави, види та форми господарсько-правової відповідальності: автореф. дис ... канд. юрид. наук: спец. 12.00 .04 «Господарське право, господарськопроцесуальне право». НАН України. Ін-т економіко-правових досліджень. Донецьк., 2010. 24 с.

6. Гуйван П. Д. Деякі правові аспекти підставності та строків захисту прав учасниками відносин з комунальних послуг. Вісник Харківського наџіонального університету внутрішніх справ. 2007. № 37. C. 286-292. URL: http://nbuv.gov.ua/UJRN/VKhnuvs_2007_37_46.

7. Вінник О. М. Господарське право: навчальний посібник. К.: Правова єдність, 2009. 768 с.

8. Про затвердження Порядку реєстрації страхових агентів, які мають право здійснювати посередницьку діяльність 3 обов'язкового страхування цивільно-правової відповідальності власників наземних транспортних засобів, у Моторному (транспортному) страховому бюро України: розпорядження Національної комісії, що здійснює державне регулювання у сфері ринків фінансових послуг від 18 квітня 2013 р. № 1270. Офіиійний вісник Украӥни. 2013. № 40. Ст. 1446.

9. Положення про реєстрацію страхових та перестрахових брокерів і ведення державного реєстру страхових та перестрахових брокерів: розпорядження Державної комісії 3 регулювання ринків фінансових послуг України від 28 травня 2004 р. № 736. Офіиійний вісник України. 2004. № 26. Ст. 116.

УДК 349.42

Ю. М. Павлюченко доцент кафедри господарського права Донецького національного університету імені Василя Стуса, канд. юрид. наук, доцент

Б. I. Кравчук студент юридичного факультету Донецького національного університету імені Василя Стуса

\section{ПРАВОВА ХАРАКТЕРИСТИКА АГРАРНИХ РОЗПИСОК}

Ключові слова: аграрні розписки, товарні аграрні розписки, фінансові аграрні розписки, товаророзпорядчий документ, кредитор, боржник, майбутній урожсай.

Аграрні розписки є відносно новим поняттям у вітчизняній аграрній сфері, запровадження якого покликане спростити сільськогосподарським товаровиробникам залучення коштів на поточні виробничі потреби. Попри те, що аграрні розписки розглядають вигідною альтернативою кредитуванню сільського господарства, вони допоки не знайшли значного розповсюдження на території України. Уведення аграрних розписок в аграрну сферу здійснюється поступово i 